\author{
ŁUKASZ DUBIŃSKI \\ ORCID: 0000-0002-9360-3892 \\ Uniwersytet Szczeciński \\ lukasz.dubinski@usz.edu.pl
}

\title{
Indywidualny akt administracji gospodarczej (próba zdefiniowania)
}

\begin{abstract}
Abstrakt: Celem artykułu jest zaproponowanie definicji pojęcia indywidualnego aktu administracji gospodarczej, rozumianego jako instrument służący ustalaniu sytuacji prawnej przedsiębiorcy. Przy okazji dowiedziono, że cechą odróżniającą indywidualne akty administracji gospodarczej od innych aktów władzy publicznej jest to, iż omawiane rozstrzygnięcia zapadają $\mathrm{w}$ wyniku przeprowadzenia procesu wyważania pomiędzy wolnością gospodarczą a innymi wartościami, które są chronione na poziomie regulacji ustrojowych. Przeprowadzone analizy mają służyć realizacji wyzwania polegającego na zbudowaniu jednolitej siatki pojęciowej, mającej na celu potwierdzenie odrębności publicznego prawa gospodarczego jako samodzielnej gałęzi prawa.
\end{abstract}

Słowa kluczowe: działalność gospodarcza, sytuacja prawna, akt indywidualny.

\section{Wprowadzenie}

W świetle dotychczasowego dorobku nauki ${ }^{1}$ teza o samodzielnym charakterze publicznego prawa gospodarczego jako odrębnej gałęzi prawa ${ }^{2}$ nie powinna budzić istotnych wątpliwości ${ }^{3}$. Nie można jednak nie zauważyć, że obecna debata

1 Zob. m.in. Swoistość procedur publicznego prawa gospodarczego, red. B. Popowska, Poznań 2014; Konstytucyjna zasada wolności gospodarczej, red. W. Szwajdler, H. Nowicki, Toruń 2009; Prawne instrumenty oddziaływania na gospodarke, red. A. Powałowski, Warszawa 2016; Dysfunkcje publicznego prawa gospodarczego, red. E. Kruk, G. Lubeńczuk, M. Zdyb, Warszawa 2018.

2 K. Strzyczkowski, Prawo gospodarcze publiczne, Warszawa 2011, s. 46; T. Rabska, Refleksje nad nauka publicznego prawa gospodarczego, „Roczniki Nauk Prawnych”21, 2011, nr 1, s. 269.

${ }^{3} \mathrm{~K}$. Kiczka, O ograniczaniu niektórych wolności w prawie gospodarczym publicznym, [w:] Nowe problemy badawcze w teorii prawa administracyjnego, red. J. Boć, A. Chajbowicz, Wrocław 2009, s. 261.

Prawo 329, 2020

(C) for this edition by CNS 
naukowa mająca za przedmiot publiczne prawo gospodarcze toczy się nie tylko wokół nowych wyzwań teoretycznoprawnych ${ }^{4}$ czy szczegółowych rozwiązań legislacyjnych ${ }^{5}$, lecz ciągle żywa pozostaje także dyskusja dotycząca rudymen-

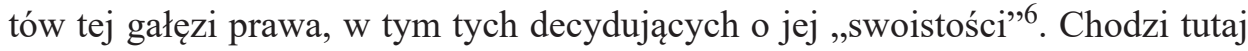
o spory koncentrujące się wokół zagadnień związanych z istotą publicznego prawa gospodarczego, czyli prawnym ujęciem sposobów i zasad ingerencji państwa w gospodarkę.

Uwzględniając ustrojowe ujęcie systemu gospodarczego, które promuje aktywność ekonomiczną jednostki, do fundamentów publicznego prawa gospodarczego koniecznie należy zaliczyć instrumenty, za pomocą których - mówiąc w pewnym uproszczeniu — państwo reguluje sytuację prawną pojedynczych przedsiębiorców. W związku z tym za cel artykułu obrano wypracowanie definicji pojęcia obejmującego wszystkie takie instrumenty, czyli indywidualnego aktu administracji gospodarczej.

\section{Problem nieistnienia spójnej siatki pojęciowej}

Analizując dorobek doktryny publicznego prawa gospodarczego, można zauważyć liczne i niezwykle cenne opracowania dotyczące fundamentów tej nauki. Jednocześnie widoczne jest jednak niewypracowanie jednolitej siatki pojęciowej, co w oczywisty sposób utrudnia debatę. Tym bardziej że przywołany mankament dotyczy niestety również pojęć podstawowych dla publicznego prawa gospodarczego. Przykładem ilustrującym istotę problemu są rozbieżności wokół rozumienia tak fundamentalnego pojęcia jak ,prawne formy działania administracji gospodarczej”. Przywołany zwrot jest bowiem w doktrynie wyjaśniany przynajmniej na trzy, zasadniczo różne sposoby:

W pierwszym ujęciu to formy organizacyjno-prawne, poprzez które administracja gospodarcza jest wykonywana $[\ldots]$. Drugie rozumienie $[\ldots]$ to $[\ldots]$ ogólne konstrukcje prawne, za pomocą których administracja gospodarcza kieruje i nadzoruje gospodarkę (akty indywidualne, takie jak decyzja administracyjna czy umowy; różne formy aktów normatywnych itd.). Pojęcie prawnych form działania administracji gospodarczej używane jest $[\ldots]$ też niekiedy na oznaczenie merytorycznej treści, konkretnego instrumentu czy środka prawnego, skonkretyzowanego przedmiotu formy praw-

4 Zob. np. L. Kieres, Publiczne prawo gospodarcze - kierunki rozwoju - nowe instytucje, [w:] Nowe problemy..., s. 273-282; K. Kokocińska, Prawny mechanizm prowadzenia polityki rozwoju w zdecentralizowanych strukturach władzy publicznej, Poznań 2014.

5 Zob. np. M. Szydło, Nadużywanie pozycji dominujacej w prawie konkurencji, Warszawa 2010; R. Molski, Porozumienia wertykalne w prawie konkurencji Unii Europejskiej oraz amerykańskim prawie antytrustowym, „Studia Prawnicze” 2003, nr 4.

${ }^{6}$ Zob. Instrumenty i formy prawne działania administracji gospodarczej, red. B. Popowska, K. Kokocińska, Poznań 2009. 
nej w sensie ścisłym, tj. typu aktu prawnego — krótko mówiąc, na oznaczenie środka prawnego będącego treścią decyzji bądź umowy lub też innego typu aktu prawnego 7 .

$\mathrm{Z}$ kolei w ramach rozważań nad instrumentami ingerencji państwa w gospodarkę widoczna jest wyraźna swoboda w zamiennym stosowaniu zwrotów na ich określenie, takich jak właśnie „forma prawna” czy też „środek”, „instrument” albo ,akt".

Przedstawiony problem nieistnienia spójnej siatki pojęciowej jest niewątpliwie konsekwencją rozpiętości materii prawnej, którą obejmuje publiczne prawo gospodarcze, przy czym nie chodzi tutaj wyłącznie o liczbę aktów prawnych, lecz także o ich różnorodność pod względem funkcji, jakie pełnią ujęte w nich rozwiązania $^{8}$.

Istotne trudności w pracy nad ujednolicaniem terminologii wiążą się również $\mathrm{z}$ tym, że ustawodawca w obszarze publicznego prawa gospodarczego wyjątkowo często zdaje się pomijać zasady prawidłowej legislacji, czyniąc tę złożoną i szeroką materię jeszcze trudniejszą do odkodowania i uporządkowania. Nie chodzi przy tym wyłącznie o negatywne zjawiska znane $\mathrm{z}$ aktów prawnych reprezentatywnych dla innych gałęzi prawa, takie jak tworzenie niezrozumiałych bądź wewnętrznie sprzecznych regulacji prawnych czy marginalizowanie znaczenia vacatio legis. W wypadku publicznego prawa gospodarczego na pierwszy plan wysuwa się bowiem wyjątkowa niedbałość terminologiczna w zakresie określania instrumentów, za pomocą których państwo ma oddziaływać na gospodarkę. $\mathrm{Na}$ to zjawisko składa się stosowanie nieużywanych wcześniej wyrażeń językowych w treści nowo przyjmowanych albo zmienianych aktów prawnych, przy jednoczesnym zaniedbaniu należytego wyjaśnienia charakteru prawnego pojęcia, które opisują. Należy także wspomnieć o nagminnym posługiwaniu się tymi samymi zwrotami na określenie instrumentów wywołujących odmienne skutki prawne lub faktyczne, również $\mathrm{w}$ regulacjach odnoszących się do tego samego organu9 ${ }^{9}$ Ponadto w uchwalanych tekstach prawnych można spotkać się ze zwrotami „klasycznymi” (na przykład „,decyzja”) ${ }^{10}$, które bez właściwego wyjaśnienia i uzasadnienia mają opisywać pojęcia w sposób zasadniczo odmienny od ich pierwotnego i ustalonego znaczenia.

7 M. Kania, K. Kiczka, M. Szydło, Formy prawne działania administracji gospodarczej, [w:] System Prawa Administracyjnego, t. 8b. Publiczne prawo gospodarcze, red. R. Hauser, Z. Niewiadomski, A. Wróbel, Warszawa 2018, https://sip.legalis.pl/document-full.seam?documentId=mjxw62zogi3damrqhazdsmq\#tabs-metrical-info (dostęp: 2.09.2019).

8 Zob. Funkcje współczesnej administracji gospodarczej, red. B. Popowska, Poznań 2006.

9 Zob. A. Trela, Zgoda jako środek prawny działania ministra właściwego do spraw skarbu państwa, [w:] Środki prawne publicznego prawa gospodarczego, red. L. Kieres, Wrocław 2007, s. 205-221.

10 Zob. B. Popowska, Partnerstwo publiczno-prywatne w świetle koncepcji „,ciagu działań prawnych" i jej wptyw na ocenę umowy o ppp, [w:] Środki prawne..., s. 148-149. 
Przeszkodą w tworzeniu spójnej siatki terminologicznej jest również to, że publiczne prawo gospodarcze opiera się na rozwiązaniach ujętych zarówno w krajowych, jak i unijnych aktach prawnych, a ponadto część jego postanowień jest wykonywana przez organy administracji europejskiej ${ }^{11}$. Innymi słowy ingerencja $\mathrm{w}$ gospodarkę nie jest dokonywana wyłącznie $\mathrm{z}$ użyciem instrumentów wykorzystywanych przez krajowe organy administracji publicznej. W rezultacie spójna terminologia powinna obejmować instrumenty, które nie są ,genetycznie jednorodne" 12 .

Należy ponadto zauważyć, że pierwowzór gałęzi prawa, jaką jest publiczne prawo gospodarcze, czyli zarządzanie gospodarką narodową, wywodzi się z prawa administracyjnego. Widoczną konsekwencją tego stanu rzeczy jest to, iż koncepcje teoretycznoprawne wypracowane w doktrynie prawa administracyjnego nierzadko były punktem wyjścia analizy rozwiązań prawnych zaliczanych do dyscypliny „zarządzanie gospodarką narodową?. Jej ścisły związek z doktryną prawa administracyjnego został zaburzony wraz ze zmianą ustroju gospodarczego, czyli wraz z odejściem od modelu zarządzania gospodarką przez państwo. Można zauważyć, iż w nauce „rozwód” prawa administracyjnego i zarządzania gospodarką narodową przekształconą w publiczne prawo gospodarcze został zbadany głównie w warstwie aksjologicznej i sferze szczegółowych rozwiązań legislacyjnych. Natomiast stosunkowo ograniczone są analizy w obszarze pojęć podstawowych, a w szczególności w zakresie oddzielania konstrukcji właściwych dla publicznego prawa gospodarczego od instytucji prawa administracyjnego.

\section{Założenia badawcze}

Sygnalizowana w poprzedniej części rozważań różnorodność funkcji publicznego prawa gospodarczego powoduje, że zadania administracji gospodarczej nie mają homogenicznego charakteru, co przekłada się również na paletę instrumentów ingerencji w gospodarkę. W tej grupie mieszczą się zarówno środki o charakterze finansowym, informacyjnym, jak i „klasyczne” instrumenty, jakimi posługuje się administracja, takie jak na przykład „decyzja”, o której mowa w k.p.a. Analogicznie jak w wypadku prawa administracyjnego można tu wyodrębnić instrumenty nakierowane na wywoływanie skutków prawnych oraz takie, których podjęcie ma za zadanie wywołać zmiany o charakterze faktycznym. Indywidualne akty administracji gospodarczej jako instrumenty mające służyć ingerencji w prawa, wolności i obo-

11 Zob. Europeizacja publicznego prawa gospodarczego, red. H. Gronkiewicz-Waltz, K. Jaroszyński, Warszawa 2011.

12 K. Strzyczkowski, Uwagi o zadaniach nauki o prawnych formach dziatania administracji gospodarczej, [w:] Instrumenty i formy prawne..., s. 39. 
wiązki związane z działalnością gospodarczą jednostki należy zakwalifikować do tej pierwszej grupy, czyli czynności prawnych w szerokim rozumieniu ${ }^{13}$.

Biorąc z kolei pod uwagę to, że omawiana forma rozstrzygnięć jako władcza forma oddziaływania państwa i Unii Europejskiej może być podejmowana wyłącznie w ramach przyznanego uprawnienia, należałoby również samo pojęcie indywidualnego aktu administracji gospodarczej wyjaśnić z uwzględnieniem perspektywy sposobu rozumienia „kompetencji” do jego wydania. W związku z tym warto zauważyć,

iż określonemu podmiotowi przysługuje w określonych okolicznościach kompetencja prawna (w szerokim znaczeniu) do dokonania w pewien sposób danej czynności prawnej [w tym indywidualnego aktu administracji gospodarczej — Ł.D.], jeśli w takich okolicznościach czynność konwencjonalna tego podmiotu dokonana w wyznaczony sposób staje się, ze względu na reguły zakładane w danym systemie prawnym, faktem prawotwórczym (czy uchylającym normę prawną) lub faktem aktualizującym (czy też dezaktualizującym) czyjeś obowiązki wyznaczone przez obowiązującą normę prawną ${ }^{14}$.

$\mathrm{Na}$ tej podstawie należy przyjąć, że rekonstrukcja pojęcia indywidualnego aktu administracji gospodarczej wymaga zidentyfikowania następujących elementów: podmiotu wydającego ten akt, jego adresata oraz podstawy i przedmiotu rozstrzygnięcia.

Przyjmując, iż celem analizy jest scharakteryzowanie pojęcia właściwego dla całej gałęzi prawa, konieczne staje się zwrócenie uwagi na dwa elementy. Po pierwsze, chodzi o podkreślenie cech wspólnych dla wszystkich instrumentów ujętych w regulacjach publicznego prawa gospodarczego. Po drugie, istotne będzie wskazanie, które $\mathrm{z}$ wyróżnionych cech pojęcia świadczą o jego przynależności wyłącznie do publicznego prawa gospodarczego.

\section{Administracja gospodarcza}

W dorobku nauki publicznego prawa gospodarczego obecne są dwa sposoby wyjaśniania pojęcia „,administracja gospodarcza”.

Pierwszy wariant opisu tego określenia sprowadza się de facto do „odtworzenia" ujęcia prezentowanego w nauce prawa administracyjnego, z zaznaczeniem, że przedmiotem działalności tego rodzaju administracji jest zajmowanie się gospodarką ${ }^{15}$.

13 Zob. Z. Ziembiński, Kompetencja i norma kompetencyjna, „Ruch Prawniczy, Ekonomiczny i Socjologiczny" 1969 , nr 4, s. 28-29.

14 Ibidem, s. 29.

15 Z. Snażyk, Administracja gospodarcza, [w:] Z. Snażyk, A. Szafrański, Publiczne prawo gospodarcze, Warszawa 2015, s. 20. 
Drugi model charakteryzowania „administracji gospodarczej” opiera się na schematach i pojęciach powoływanych na potrzeby nauki publicznego prawa gospodarczego. Do przedstawicieli takiego podejścia niewątpliwie można zaliczyć K. Strzyczkowskiego. Zdaniem tego autora można mówić o przedmiotowym, podmiotowym i funkcjonalnym ujęciu administracji gospodarczej ${ }^{16}$. W pierwszym z wymienionych wariantów (przedmiotowym) chodzi o „wynikającą z materialnego ustawodawstwa administracyjno-gospodarczego działalność organów administracji publicznej w zakresie ingerencji publicznej w gospodarkę" ${ }^{17}$. Upraszczając, wyodrębnienie administracji gospodarczej w prezentowanym ujęciu jest pochodną przedmiotu jej aktywności, a nie wydzielenia jej organów w strukturze całej administracji. Ten drugi wariant jest bowiem określany przez K. Strzyczkowskiego jako ujęcie podmiotowe ${ }^{18}$. Autor ocenia jednak takie rozumienie administracji gospodarczej krytycznie, ponieważ jego zdaniem prowadzi ono do pominięcia jednostek zaangażowanych $\mathrm{w}$ ingerencję państwa w gospodarkę, które jednocześnie wykonują inne zadania (na przykład z zakresu ochrony środowiska) ${ }^{19}$. W związku z tym jako najtrafniejsze badacz uznaje ujęcie funkcjonalne administracji gospodarczej, które „oznacza realizację w zakresie i kształcie wyznaczonym przez prawo gospodarcze publiczne funkcji ingerencji publicznej w gospodarkę bez względu na zakres i charakter podmiotów, które uczestniczą w jej realizacji" 20 .

Z kolei C. Banasiński mówi o dwóch rodzajach administracji gospodarczejbezpośredniej i pośredniej ${ }^{21}$. Pierwszą z nich mają tworzyć „naczelne, centralne $i$ terenowe organy administracji rządowej" 22 . Natomiast administracja gospodarcza pośrednia ,jest [...] wykonywana zarówno w drodze wykorzystania instytucji zlecania zadań i funkcji administracji" ${ }^{23}$, jak i przez jednostki kontrolowane przez organy administracji rządowej ${ }^{24}$. Podstawą wyodrębnienia zarówno administracji gospodarczej bezpośredniej, jak i pośredniej jest przy tym przedmiot ich działalności, będący oddziaływaniem państwa na gospodarkę $e^{25}$.

Warto również przywołać interesujące podejście C. Kosikowskiego, w którego ujęciu administrację gospodarczą tworzą tak zwane podmioty czynne, rozumiane jako jednostki realizujące zadania i kompetencje w imieniu państwa oraz

16 K. Strzyczkowski, Prawo..., s. 120-123.

17 Ibidem, s. 120.

18 Ibidem, s. 121.

19 Ibidem, s. 121-122.

20 Ibidem, s. 122-123.

21 C. Banasiński, Organizacja administracji właściwej w sprawach gospodarki, [w:] Prawo gospodarcze Zagadnienia administracyjnoprawne, red. H. Gronkiewicz-Waltz, M. Wierzbowski, Warszawa 2009, s. 81-82.

22 Ibidem, s. 82.

23 Ibidem.

24 Ibidem.

25 Ibidem. 
Unii Europejskiej wobec gospodarki, i tak zwane podmioty bierne, postrzegane jako jednostki „wykonujące we własnym imieniu działalność gospodarczą lub zawodową" 26 .

Opierając się na przytoczonych podejściach, można przyjąć, że podstawą wyróżniania jednostek tworzących administrację gospodarczą jest ich zaangażowanie w oddziaływanie na gospodarkę, a nie ich cechy indywidualne. Innymi słowy zaliczenie określonych jednostek do administracji gospodarczej jest wtórne w stosunku do zadań, jakie one wykonują. Nie można więc na podstawie właściwości danego organu, takich jak jego budowa, sposób działania czy miejsce w strukturze administracji, ocenić, czy jego działanie jest indywidualnym aktem administracji gospodarczej.

\section{Adresaci indywidualnych aktów administracji gospodarczej}

Adresatami indywidualnych aktów administracji gospodarczej są podmioty prowadzące działalność gospodarczą (dalej — dla klarowności przekazu — określani także jako przedsiębiorcy). W związku z tym założeniem poczynić należy kilka zastrzeżeń. W pierwszej kolejności należy przypomnieć, że w systemie prawnym nie ma jednej definicji działalności gospodarczej. Indywidualnym aktem administracji gospodarczej będzie więc wyłącznie akt kierowany do podmiotu, którego aktywność może zostać zakwalifikowana jako działalność gospodarcza zgodnie z przepisami, na których podstawie został wydany akt do niego skierowany.

Gospodarczy charakter danego aktu nie jest jednak wyłącznie pochodną statusu jego adresata jako przedsiębiorcy, lecz także właściwości jego aktywności, będącej przedmiotem danego rozstrzygnięcia. Innymi słowy za indywidualny akt administracji gospodarczej można uznać wyłącznie takie rozstrzygnięcie, które jest kierowane do przedsiębiorcy w związku z prowadzoną przez niego działalnością gospodarczą.

W związku z tym należy zauważyć, że na podstawie rozwiązań obecnych w poszczególnych gałęziach prawa mogą być przyjmowane rozstrzygnięcia spełniające opisane już wymogi. Za przykład mogą posłużyć rozstrzygnięcia organów skarbowych, które są podejmowane w sprawach dotyczących opodatkowania działalności gospodarczej przedsiębiorców. Należy więc przyjąć, iż bezpośredni związek rozstrzygnięcia z charakterem jego adresata (czyli przedsiębiorcy) oraz jego aktywności (działalności gospodarczej) stanowią cechy konstytutywne indy-

26 C. Kosikowski, Publiczne prawo gospodarcze Polski i Unii Europejskiej, Warszawa 2010, s. $50-51$. 
widualnego aktu administracji gospodarczej, lecz ich wystąpienie nie przesądza o takim charakterze danej czynności organu.

\section{Przedmiot i podstawa prawna indywidualnego aktu administracji gospodarczej}

Na wstępie należy przypomnieć, że tak jak sygnalizowano wcześniej, publiczne prawo gospodarcze tworzy niezwykle liczna grupa aktów prawnych o odmiennych przedmiotach regulacji. W rezultacie, mówiąc o wspólnym przedmiocie indywidualnych aktów administracji gospodarczej, można jedynie co najwyżej powiedzieć, że dotyczy on gospodarki. Z łatwością można zauważyć, iż na tym poziomie ogólności można powiązać $\mathrm{z}$ tą dziedziną życia społecznego również akty wywodzące się z innych gałęzi prawa (na przykład podatkowego).

Należy także zauważyć, że wskazana mnogość rozwiązań prawnych powoduje, że rozstrzygnięcia wydawane w obrębie publicznego prawa gospodarczego służą realizacji różnorodnych funkcji. Przykładowo nie można postawić znaku równości między celami stojącymi za decyzjami wydawanymi przez Prezesa Urzędu Ochrony Konkurencji a tymi, które przyświecają udzielaniu zezwoleń na sprzedaż alkoholu.

Trzeba też zwrócić uwagę na różnorodny charakter skutków oddziaływania poszczególnych rodzajów aktów, które można uznać za reprezentatywne dla publicznego prawa gospodarczego. W tym gronie można bowiem wyróżnić zarówno rozstrzygnięcia dające podstawę do ,podejmowania i ochrony wykonywania [...] działalności gospodarczej” (tak zwane decyzje uprawniające) ${ }^{27}$, jak i decyzje nakładające obowiązki (tak zwane decyzje obligacyjne) $)^{28}$ bądź sankcje (tak zwane decyzje sankcjonujące $)^{29}$. Ponadto należy wspomnieć o tak zwanych aktach kwalifikujących, które „nie kształtują bezpośrednio konkretnych uprawnień i obowiązków jednostki, lecz tylko odnoszą się do stwierdzenia cech (właściwości) osób i rzeczy (zespołów rzeczy)"30. Patrząc z tej perspektywy, nie można zatem mówić o wspólnej tożsamości indywidualnych aktów administracji gospodarczej i to zarówno pod kątem sposobów kształtowania sytuacji prawnej ich adresatów, jak i celów ustawowych, którym mają służyć.

Również w związku z rozpiętością materii legislacyjnej w obszarze publicznego prawa gospodarczego nie można mówić o precyzyjnej wspólnej podstawie

27 Przedstawiona decyzja wraz z cytatem pochodzi z: M. Kania, K. Kiczka, M. Szydło, op. cit.

28 Ibidem.

29 Ibidem.

${ }^{30}$ K. Kiczka, Administracyjne akty kwalifikujące w działalności gospodarczej, Wrocław 2006, s. 76-77. 
do wydawania indywidualnych aktów administracji gospodarczej. Niemniej jednak odwołując się do wcześniejszych ustaleń, warto zauważyć, że każde rozstrzygnięcie gospodarcze o charakterze indywidualnym zmierza do zmiany sytuacji prawnej konkretnego adresata w obszarze jego działalności gospodarczej. Z perspektywy krajowych i unijnych rozwiązań ustrojowych należy przez to rozumieć władczą ingerencję w sferze jednej z podstawowych wartości (wolności gospodarczej), która pozostaje jednocześnie jednym z filarów przyjętego systemu gospodarczego (zasady społecznej gospodarki rynkowej). W takim ujęciu można wyodrębnić dwa typy oddziaływań władzy publicznej.

W pierwszym wariancie chodzi o rozstrzygnięcia niosące negatywne konsekwencje dla ich adresatów. Mowa tutaj o aktach skutkujących ograniczeniem czy nawet pozbawieniem możliwości prowadzenia działalności gospodarczej albo takich, które mają służyć korygowaniu zachowań przedsiębiorcy (na przykład przez nałożenie kary pieniężnej) czy nakładaniu na nich dodatkowych obowiązków. W tej grupie rozstrzygnięć znajdą się wspominane decyzje obligacyjne oraz sankcjonujące.

Drugi rodzaj władczego oddziaływania w sferze wolności gospodarczej jest natomiast pozytywny w skutkach dla jego adresatów. W tym wypadku mowa bowiem o decyzjach, które w bezpośredni (decyzje uprawniające) lub co najmniej pośredni sposób (akty kwalifikujące) umożliwiają podejmowanie lub wykonywanie działalności gospodarczej.

Należy przy tym zauważyć, że wymienione poszczególne rodzaje rozstrzygnięć łączy nie tylko sfera, na jaką oddziałują (to jest wolność działalności gospodarczej), lecz także perspektywa, z jakiej są podejmowane, czyli inne wartości chronione na poziomie regulacji ustrojowych (na przykład życie ludzkie czy środowisko naturalne). Można bowiem zauważyć, iż rozstrzygnięcia negatywne zasadniczo służą eliminacji zaistniałych lub potencjalnych zagrożeń dla tych wartości, podczas gdy decyzje pozytywne potwierdzają brak niebezpieczeństwa dla nich. Chodzi tutaj oczywiście o zagrożenia i niebezpieczeństwa mające swoje źródło w działalności gospodarczej.

Biorąc z kolei pod uwagę fakt, że sama wolność gospodarcza jako taka jest odrębną wartością chronioną na poziomie regulacji ustrojowych, należy stwierdzić, że zarówno rozstrzygnięcia ze sfery negatywnej, jak i pozytywnej nie mogą prowadzić do jej wyeliminowania czy takiego ograniczenia, które pozbawia ją jej sensu. Posługując się językiem ustawy zasadniczej, należałoby mówić o zakazie podejmowania rozstrzygnięć godzących $\mathrm{w}$ istotę wolności gospodarczej w imię ochrony innych wartości.

Ponadto istota wolności gospodarczej jako odrębnej wartości oznacza, iż prawodawca zakłada możliwość swobodnego z niej korzystania, w tym kosztem wprowadzania ograniczeń w sferze innych wartości. Tym samym nie należy sprowadzać funkcji indywidualnych aktów administracji gospodarczej wyłącznie do wskazanej ochrony wolności gospodarczej. Należy więc powiedzieć, że to na reprezentantach władzy wykonawczej spoczywa obowiązek rozstrzygania gwarantującego możli- 
wość swobodnego podejmowania, wykonywania i zakończenia działalności gospodarczej w granicach obowiązującego prawa, a więc również innych wartości chronionych prawnie wyznaczających sposób rozumienia jego treści.

$\mathrm{Na}$ tej podstawie można więc sformułować tezę, że wydawanie indywidualnych aktów administracji gospodarczej (zarówno negatywnych, jak i pozytywnych) jest każdorazowo procesem polegającym na wyważaniu pomiędzy wolnością działalności gospodarczej a innymi wartościami chronionymi prawnie.

\section{Podsumowanie}

Opierając się na przeprowadzonej w tekście analizie oraz prezentowanej w dalszej części tekstu propozycji definicji indywidualnego aktu administracji gospodarczej, konieczne wydaje się podkreślenie cechy właściwej w y łą c z ni e klasie omawianych rozstrzygnięć. Otóż wydawanie indywidualnych aktów administracji gospodarczej jest uwarunkowane aksjologicznie (wolność gospodarcza) i ustrojowo (społeczna gospodarka rynkowa), co odróżnia je od „klasycznych” aktów administracji publicznej, takich jak decyzja administracyjna, które nie są odgórnie związane z konkretną paletą wartości.

Przechodząc do istoty sprawy, proponuje się przyjęcie, że indywidualnym aktem administracji gospodarczej jest czynność prawna wyodrębnionej jednostki organizacyjnej podejmowana w imieniu i na rachunek państwa albo Unii Europejskiej w stosunku do przedsiębiorcy, ze względu na jego działalność gospodarczą, w celu zmiany jego sytuacji prawnej w wyniku przeprowadzenia procesu wyważania pomiędzy wolnością gospodarczą a innymi wartościami, które są chronione na poziomie regulacji ustrojowych.

\section{Bibliografia}

Banasiński C., Organizacja administracji właściwej w sprawach gospodarki, [w:] Prawo gospodarcze. Zagadnienia administracyjnoprawne, red. H. Gronkiewicz-Waltz, M. Wierzbowski, Warszawa 2009.

Dysfunkcje publicznego prawa gospodarczego, red. E. Kruk, G. Lubeńczuk, M. Zdyb, Warszawa 2018.

Europeizacja publicznego prawa gospodarczego, red. H. Gronkiewicz-Waltz, K. Jaroszyński, Warszawa 2011.

Funkcje współczesnej administracji gospodarczej, red. B. Popowska, Poznań 2006.

Instrumenty i formy prawne działania administracji gospodarczej, red. B. Popowska, K. Kokocińska, Poznań 2009.

Kania M., Kiczka K., Szydło M., Formy prawne działania administracji gospodarczej, [w:] System Prawa Administracyjnego, t. 8b. Publiczne prawo gospodarcze, red. R. Hauser, Z. Niewiadomski, A. Wróbel, Warszawa 2018. 
Kiczka K., Administracyjne akty kwalifikujące w działalności gospodarczej, Wrocław 2006.

Kiczka K., O ograniczaniu niektórych wolności w prawie gospodarczym publicznym, [w:] Nowe problemy badawcze w teorii prawa administracyjnego, red. J. Boć, A. Chajbowicz, Wrocław 2009.

Kieres L., Publiczne prawo gospodarcze - kierunki rozwoju - nowe instytucje, [w:] Nowe problemy badawcze w teorii prawa administracyjnego, red. J. Boć, A. Chajbowicz, Wrocław 2009.

Kokocińska K., Prawny mechanizm prowadzenia polityki rozwoju w zdecentralizowanych strukturach wtadzy publicznej, Poznań 2014.

Konstytucyjna zasada wolności gospodarczej, red. W. Szwajdler, H. Nowicki, Torun 2009.

Kosikowski C., Publiczne prawo gospodarcze Polski i Unii Europejskiej, Warszawa 2010.

Molski R., Porozumienia wertykalne w prawie konkurencji Unii Europejskiej oraz amerykańskim prawie antytrustowym, „Studia Prawnicze” 2003, nr 4.

Popowska B., Partnerstwo publiczno-prywatne w świetle koncepcji „ciagu działań prawnych” i jej wplyw na ocenę umowy o ppp, [w:] Środki prawne publicznego prawa gospodarczego, red. L. Kieres, Wrocław 2007.

Prawne instrumenty oddziaływania na gospodarke, red. A. Powałowski, Warszawa 2016.

Rabska T., Refleksje nad nauka publicznego prawa gospodarczego, „Roczniki Nauk Prawnych” 21, 2011, nr 1.

Snażyk Z., Administracja gospodarcza, [w:] Z. Snażyk, A. Szafrański, Publiczne prawo gospodarcze, Warszawa 2015.

Strzyczkowski K., Prawo gospodarcze publiczne, Warszawa 2011.

Strzyczkowski K., Uwagi o zadaniach nauki o prawnych formach działania administracji gospodarczej, [w:] Instrumenty i formy prawne dziatania administracji gospodarczej, red. B. Popowska, K. Kokocińska, Poznań 2009.

Swoistość procedur publicznego prawa gospodarczego, red. B. Popowska, Poznań 2014.

Szydło M., Nadużywanie pozycji dominującej w prawie konkurencji, Warszawa 2010.

Trela A., Zgoda jako środek prawny działania ministra właściwego do spraw skarbu państwa, [w:] Środki prawne publicznego prawa gospodarczego, red. L. Kieres, Wrocław 2007.

Ziembiński Z., Kompetencja i norma kompetencyjna, „Ruch Prawniczy, Ekonomiczny i Socjologiczny" $1969, \mathrm{nr} 4$.

\section{Individual act of economic administration (attempt to define)}

\section{Summary}

The purpose of the article is to propose a definition of the concept of an individual act of economic administration understood as an instrument for determining the legal situation of an entrepreneur. By the way, it was found that the feature that distinguishes individual acts of economic administration from other acts of public authority is that the discussed decisions are made as a result of balancing between economic freedom and other values that are protected at the level of systemic regulations. The analyzes carried out are intended to fulfill the challenge of building a unified conceptual grid, which is to confirm the separateness of public commercial law as an independent branch of law.

Keywords: economic activity, legal situation, individual act. 